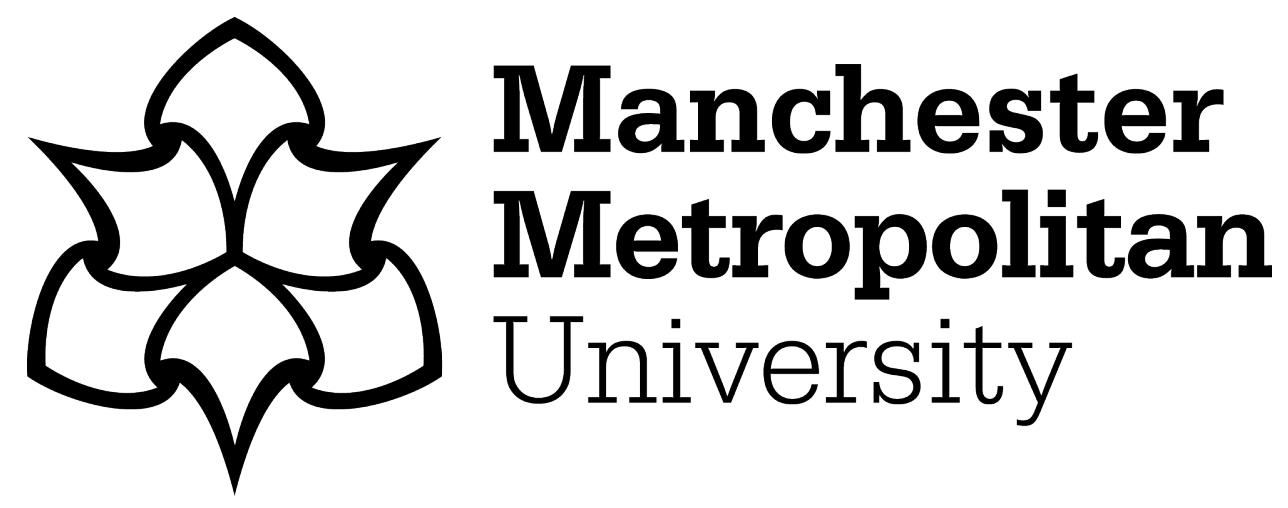

Madoc-Jones, I, Ahmed, A ORCID logoORCID: https://orcid.org/0000-00026164-0656, Hughes, C, Dubberley, S, Gorden, C, Washington-Dyer, K, Lockwood, K and Wilding, M (2019) Imaginary Homelessness Prevention with Prison Leavers in Wales. Social Policy and Society, 19 (1). pp. 145-155. ISSN 1474-7464

Downloaded from: https://e-space.mmu.ac.uk/625882/

Version: Accepted Version

Publisher: Cambridge University Press

DOI: https://doi.org/10.1017/S1474746419000356

Usage rights: Creative Commons: Attribution-Noncommercial-No Derivative Works 4.0

Please cite the published version 


\section{Imaginary Homelessness Prevention with Prison Leavers in Wales}

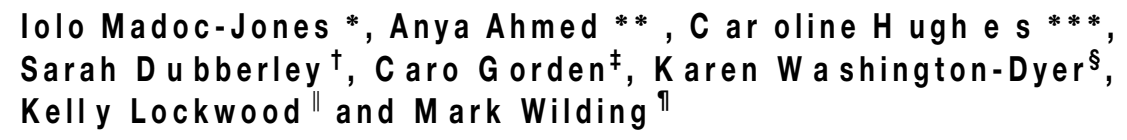

In this article we engage in a critical examination of how local authority Housing Solutions staff, newly placed centre stage in preventing homelessness amongst prison leavers in Wales, understand and go about their work. Drawing on Carlen's concept of 'imaginary penalities' and Ugelvik's notion of 'legitimation work' we suggest practice with this group can be ritualistic and underpinned by a focus on prison leavers' responsibilities over their rights, and public protection over promoting resettlement. In response we advocate for less-punitive justice and housing policies, underpinned by the right to permanent housing for all prison leavers and wherein stable accommodation is understood as the starting point for resettlement. The analysis presented in this article provides insights to how homelessness policies could play out in jurisdictions where more joint working between housing and criminal justice agencies are being pursued and/or preventative approaches to managing homelessness are being considered.

Keywords: Prison, homelessness, resettlement, housing, prevention.

\section{Introduction}

Entitlement to housing has always been conditional in England and Wales and for most of the last forty years, statutory assistance for people facing homelessness has been reserved 
for those deemed to be in priority need, unintentionally homeless and with local connections. Historically, prison leavers have been poorly served by legislation, not least because they could be readily classified as 'intentionally homeless' by dint of committing a crime in the first place (Mackie, 2008). A third of offenders are without a home before imprisonment (Social Exclusion Unit, 2002; Gojkovic et al., 2012). A similar proportion of prison leavers (amounting to around 30000 people a year) report being homeless on release. Being homeless increases the chances of reoffending. In 2012 it was suggested that more than three-quarters of prisoners (79 per cent) who reported being homeless before custody were reconvicted in the first year after release, compared with about half (47 per cent) of those who did not (Ministry of Justice, 2012).

Rough sleeping is the most visible but by no means the only manifestation of the failure to address prison leaver homelessness. Estimating the numbers of people sleeping rough is notoriously difficult and Wales specific data is sparse, but data published in 2016 suggested that the UK total was up by 55 per cent since 2010 (Fitzpatrick et al., 2016). According to the National Audit Office (2017) the number of people sleeping rough has increased by 134 per cent over the same time period. In November 2016 the Welsh Government conducted their second annual count of people sleeping rough across Wales and recorded a 72 per cent rise compared to 2015 (Welsh Government, 2017). Data from 2014/2015 suggests that 32 per cent of rough sleepers had been to prison at some point (Clinks Briefing, 2017). Ministry of Justice (2019) data shows a twenty-five-fold increase between October 2016 and June 2018 in rough sleeping among those who have served sentences of less than six months. Overall, a quarter of short-sentenced prisoners were released homeless, almost double the rate in October 2016.

Recently, however, the Wales (Housing) Act 2014 has placed new duties on Local Authorities to 'help to prevent' or 'help to secure' accommodation in all cases where an individual or family is facing homelessness. This includes prison leavers. The details are discussed in an introductory article to this themed section (Ahmed and Madoc-Jones, 2019); but, to reiterate, it was intended the legislation would underpin a change in organisational culture from a procedurally driven bureaucratic approach focusing on assessing whether statutory duties were owed, towards a more person-centred/partnership approach to working with homeless individuals and families to address their needs. In the case of prison leavers in Wales, 'The National Pathway for Providing Services to Children, Young People and Adults in the Secure Estate' (Welsh Government, 2015) emphasised the importance of joint working between prison leavers, health, criminal justice and social care agencies to try to ensure reasonable steps are taken to make accommodation available on release, and that support is provided to maintain tenancies thereafter (Welsh Government, 2015).

In a previous report (Madoc-Jones et al., 2018) and article (Madoc-Jones et al., 2019), however, we have shown that the housing needs of prison leavers are still not being adequately assessed and addressed. Here we examine why this is the case by exploring how local authority Housing Solutions staff talk about their experience of this work. Cooper (2016) argues that with few exceptions the role of local housing authorities is often considered to be irrelevant when it comes to understanding prisoner resettlement and homelessness. Addressing this seems important, especially as staff have recently moved away from presiding over a housing allocation system to being placed centre stage in meeting the needs of prison leavers facing homelessness in Wales. On the basis that their theories can illuminate our understanding of preventative homelessness practices with prison leavers, this article takes its conceptual lead from Carlen (2013) and Ugelvik (2016). Carlen coined the term 'imaginary 
penality' to denote the fictive knowledge, practices and organisational consciousness formed when there is a gap between the demands placed on staff and the social conditions in which those demands have to be met. Ugelvik (2016) argued that where staff face external and internal criticism of their work (as those seeking to address prison leaver homelessness may face from homelessness charities; prison staff; social landlords and prison leavers themselves) they may come to understand their activity lacks legitimacy. In response they may then engage in 'backstage narrative legitimation work' to make sense of it (2016: 216) and to be able 'to look in the mirror and respect what they see' (2016: 228).

The article is presented in four parts. First a critical account of the context in which attempts to address the housing needs of prison leavers operates is offered. The nature of new preventative approaches with regard to prison leavers in Wales is also explained. Second, the methods underpinning the research upon which this article draws, and the approach to sampling, data collection and analysis are outlined. The third part considers the findings. Here, with reference to the work of Carlen (2013) and Ugelvik (2016), a critical examination of policy and how it was implemented is presented. The article concludes with some consideration of how policy and practice could be modified to improve outcomes for prison leavers facing homelessness in Wales. In the context that several European countries, e.g. Bulgaria and Romania, are looking to England and Wales for models of criminal justice practice (Canton, 2010), the analysis presented in this article provides insight into how homelessness policies could play out in other jurisdictions where more joint working between housing and criminal justice agencies are being pursued and/or preventative approaches to managing homelessness are being considered.

\section{The housing and the criminal justice context}

The housing and criminal justice context may be understood with reference to globalisation, the inter-dependence of national economies and the fragmentation of social relations and identities. Consonant with a focus on the individual, neo-liberalism has emerged as the dominant political philosophy in the West, and values and sentiments underpinning responsible self-government and morally desired behaviours have been channelled into the public realm (Flint and Nixon, 2006). In this process, social ills such as homelessness have been constructed as products of agency, immorality or personal failure rather than having structural causes (Dwyer et al., 2014). In turn social order and cohesion has been promoted not as a by-product of the common citizenship associated with the welfare state, but through the exclusive operation of criminal justice and what Feeley and Simon (1994) refer to as an actuarial approach to justice. The actuarial approach assesses and categorises the risk of causing harm and deploys technologies of information-gathering and surveillance to monitor, control and at times exclude problem groups (Cowan et al., 2001; Kemshall and Maguire, 2001). Social order and cohesion are further promoted through what Foucault termed 'governmentality'; the central feature of which is the state seeking to 'govern at a distance', or through proxies rather than directly (Garland, 1997). Simon (2007) refers to the phenomenon of 'governing through crime' so that the boundaries between agencies from different policy fields, such as housing and policing, become blurred. The criminology literature refers to a growth in the semi-penal estate and the prison-industrial complex over the last few decades, wherein charities, welfare agencies and private companies have become increasingly embroiled in and committed to what White (2013) calls the 'Shadow State'. 
In this context, Wakefield (2003) argues that spatial boundaries are erected to maintain distance between preferred and stigmatised social groups who are pushed into

geographically marginal spaces. 'Spatial purification' (Sibley, 1995), however, depends on an alternative space being found for those who are excluded. The prison is one such

space where large number of people who are homeless find themselves confined. The poverty, visible nature and survival necessities associated with being homeless and the conditionalities attendant on bail and early release eligibility all serve to ensure that being homeless inflates the likelihood of ending up in custody and staying there longer (Cooper, 2013). Subsequent to the economic downturn of 2008, successive UK Governments have ideologically and practically committed themselves to austerity policies across the public services. A raft of measures in the Welfare Reform and Work Act 2012 (WRWA) have worsened the financial position of those dependant on benefits and made them unattractive as tenants. The absence of social housing or other suitable affordable accommoda-

tion represents a significant additional challenge to addressing homelessness. Social housing provision has atrophied, and home building has been in decline increasing demand, and thereby costs, for private rental properties (Stephens and Stephenson, 2016).

\section{The study: an evaluation of the homelessness services provided to adults leaving the secure estate (Wales)}

The data was gathered as part of a broader Welsh Government funded evaluation of 'The National Pathway for Providing Services to Children, Young People and Adults in the Secure Estate' (Welsh Government, 2015) (hereafter 'The National Pathway'). The study adopted a mixed methods approach and engaged with 114 professional stakeholders with responsibilities associated with addressing homelessness amongst prison leavers and seventy-five prison leavers. All interviews were recorded and transcribed verbatim. The study was approved by the National Research Council and Glyndwr University's Research Ethics Committee. Consonant with obtaining approval, issues of informed consent, confidentiality and anonymity were addressed, and researchers followed a Managing Distress and Managing Disclosures Policy. The findings here, presented thematically, and through an interpretive lens, draw from the larger study, but focus exclusively on data gathered during interviews with the twenty-one local authority 'housing solution' workers (respondents HO1-HO21). Their main functions were to receive referrals about and assess prison leavers' housing and support needs and a representative from each of the twenty-two Local Authority areas in Wales was interviewed.

\section{Findings}

In this section we report on how local authority housing solution staff talked about preventative work with prison leavers. As highlighted, we take our analytical lead from Carlen (2013) and Ugelvik (2016). First, we suggest that because of ideological and structural constraints, homelessness prevention practice with prison leavers is an imaginary penality. We then argue the inability to meet the goal of preventing homelessness amongst prison leavers is managed through legitimisation work. This takes the form of housing solutions staff embracing neo-liberal discourse about the causes of homelessness and emphasising a prison leaver's responsibility for their homelessness over rights to 
housing. Alternatively, housing solutions staff re-assess their work to focus on the contribution they could make to managing risk and public protection.

\section{Imaginary penality}

Housing Solutions staff in our research referred to new prevention policies leading to greater joint working between agencies to address homelessness amongst prison leavers. However, whilst they often talked positively about new practices and levels of cooperation, they simultaneously understood themselves to be unable to meet the objectives of trying to address homelessness amongst prison leavers because: practical difficulties arise in working through the prison walls; prison leavers are not preferred as tenants; prison leavers rarely engage with housing services once they have left prison; and there is a shortage of social and affordable housing across Wales (for full details see Madoc-Jones et al., 2018; Madoc-Jones et al., 2019). So, for example, one respondent suggested:

We work much more closely with probation since the pathway came in and where possible we share information and make decisions together so things have really improved.... but I have seen my colleagues and myself in the past spend days phoning around landlords, phoning around estate agents to try and find accommodation for people, but you look in your average estate agent and they'll have a flat for rent and it'll say 'No DHS'(sic) no benefits, and so they're clearly not wanting a prison leaver, they can be choosy so straight away you've got a problem and it's a lot of effort for very little chance of success (Respondent HO3)

When referrals were received, assessments were undertaken, information was shared between probation, prison and housing authorities, cases were discussed, and some efforts to source accommodation for prison leavers were made. However, accounts of practice suggested staff performed only 'as if' their actions might be meaningful, not with any expectation that it would be as in the following accounts:

The pathway works really well at times and in theory it could all the time. So, If I get a referral, I'll deal with it. I'll see what's available and what the need is but if I'm honest there isn't anything I can really do because prison leavers are impossible to find places for and rarely engage with us after release (HO17)

It's a good system because everyone is clear what they have to do, I get the referral I assess the information, I can't usually get into prison but I'll see them when I can, maybe on release and if they turn up I'll try to identify where they might go, speak to probation, but there isn't the places round here for them, the landlords don't want people claiming benefits and most prison leavers are single, they won't stay in touch because they know they are single so won't meet our criteria (HO6)

In sum, 'The National Pathway' was revealed as an imaginary penality (Carlen, 2013). It is based on imaginary prisons (that housing officers can penetrate); imaginary prisoners (who maintain contact with statutory agencies); imaginary communities (willing to receive prison leavers) and imaginary resources (accommodation which prison leavers can occupy). The pathway promises that crime can be prevented but provides the foundation only for imaginary homelessness prevention practice that has little chance of addressing the housing needs of prison leavers.

Carlen (2013) references a state of mind that can arise where an imaginary penalty or a fiction prevails. So, as in the above extracts, practitioners simultaneously recognise and ignore the fiction and eulogise their adherence to the routines of their work rather than the 
outcomes that are achieved. This procedural consciousness offers a means for staff to make sense of their work and 'get by'. However, one of Carlen's central arguments is that imaginary penalities are problematic because they are obstructive of 'truth' and close off new knowledge and more radical approaches to practice (Carlen, 2013: xvi).

\section{'Responsibilisation'}

In addition to this, drawing on Ugelvik (2016: 216) we argue that where staff come to understand their activity lacks legitimacy they may engage in 'backstage narrative legitimation work'. So, we found that staff frequently gave accounts of their actions that echo broader concerns with agency over structure and responsibility over rights. To explain further, in the following extract a Housing Solutions respondent relates their experiences of working with prison leavers:

A lot of the time they will come to you and they are not committed, but if they seem committed you will put them in accommodation and part of the plan says that 'you have to engage with the support that is provided', 'you see your drugs worker', and 'you see your probation officer'. Well if you find that they haven't kept appointments you can say 'we are ending your tenancy because you are not committed' ... if they are not cooperating and if you suggest something reasonable and they are not engaging, you know... they are wasting your time and you are wasting it as well. (HO9)

In this extract the 'problem of homelessness' is located at the level of the prison leaver who is not committed to be being rehoused. Commitment to change is not understood as a quality that has to be nurtured. Rather it is understood as a something that inheres, or not, in the prison leaver and forms a pre-requisite for accommodation. In these circumstances, housing is conceived as the last step in the resettlement and rehabilitation process. That is to say a reward for being committed to conventionality, rather than a right or the foundation for resettlement or rehabilitation.

As a result of new legislation and a focus on partnership working there was an expectation that prison leavers would be active in finding their own solutions to homelessness. Whilst the view that homeless people are entirely at the mercy of circumstances and lack agency is problematic, prison leavers could be responsibilised without sufficient consideration that they may not have been exposed to the social circumstances that would increase their capacity to act determinedly in their own best interests:

The last time he came out and came to us it just seemed he was really keen, as if there was something different, so I thought l'd give him a chance to show he could do it ... so probation weren't doing anything so we put some time into it and found him a place, got him to sign a contract to say he'd do this and not do that, and we were just sorting out some support, but he was back in his old ways and his friends were round there drinking, causing problems, he was missing appointments, all sorts of issues and so that fell apart. (HO11)

The intention here is not to sidestep the likelihood that the prison leaver being discussed was difficult to engage. However, in the above extract the prison leaver is extracted from their social context, largely perceived as the author of their own circumstances and responsible for changing themselves.

A number of individuals were identified in the research as revolving door clients. That is to say, prison leavers serving very short-term sentences before being released without accommodation, only to offend again in a few days and being re-admitted to custody. 
In the following extract a Housing Solutions respondent reflects on the difficulties addressing homelessness amongst this group of people:

Lots of them are just repeat offenders, in prison and then out, back in again. We set them up but within weeks they've reoffended again - that's just the cycle they are in and until they're ready to come out, to exit that cycle if you want there isn't much we can do. So, what we do is straight away we put conditions on helping: 'you will report on release' and that's a requirement for us helping you find accommodation and then 'if you don't engage then that's it'. (HO13)

Here, breaking the cycle of offending and homelessness is again presented as a matter of individual commitment and motivation as opposed to a process involving numerous lapses (Maguire and Raynor, 2006). Notwithstanding the absence of an explicit statement, it is possible to identify certain assumptions embedded in the approach. First, that behaviour will be improved in response to the threat of harsher sanctions, and, second, that settled accommodation should follow on from, rather than precede, a commitment to change. In the preceding extract the need for the prison leaver to sign a contract redolent of the one they might sign on release from custody is mentioned. Thus, housing staff are actively embroiled in surveillance of the prison leaver and a supervisory and disciplinary role.

\section{Managing risk and public protection}

Practice with prison leavers could also be legitimised through a focus on the contribution staff made to managing risk and public protection. More formal processes for sharing information have been established to coincide with new homelessness prevention duties and this had made some Housing Solutions staff perceive themselves as newly party to, and responsible for, public protection matters:

We usually get information late but at least we get it now and previously we might not get anything... the work could be a lot easier when maybe you didn't have that level of information - you'd work with the client but now there's a lot more people, there's a lot more information so you're working together and focussed on managing risks. (HO5)

In the above extract a concern with risks - an issue that has become of primary concern in criminal justice practice - is foregrounded and a certain 'groupthink' about this issue amongst those involved in addressing homelessness among prison leavers is identified. In the following extract another respondent describes their priorities and practices when it comes to assessing homeless prison leavers:

What's good about how things are now and it's much better is that theoretically at least is that everyone should be working together, so we get a lot more information than we used to and you can actually address the risks ... I've got to think about where to put them or recommend, recommend is nearer - because of issues of risk, of harm, of reoffending, risk to others, I would, I would be looking at the potential risk of harm to others, to a child they are in a relationship with, where there's a potential there now or never really, are they mentally ill, have they suffered trauma, will they hurt themselves. I'd be looking at all of that and the chances of that person committing a further offence or maybe even re-victimizing a person they are related to. (HO8)

Work with prison leavers has traditionally been undertaken across the divide that exists between a concern to promote opportunities for resettlement and protect the public. However, the focus here is on protecting the public. The term 'risk' is used imprecisely, 
and it is not clear whether the concern is with the 'likelihood of re-offending', 'risk of serious harm to others', 'vulnerability' and/or 'self-harm'. The respondent embraces the language of 'risk management' and 'public protection' in preference to language that focuses on a prison leaver's housing needs.

In the next extract, another housing solutions respondent refers to their practice with prison leavers:

So once you've got the referral from probation and prison you're always asking yourself 'have they made a commitment', to change, the last thing anyone wants is someone causing real problem somewhere they've been placed, someone being a risk and so you want to avoid that, It's one thing if something happens but if its if you've placed them somewhere and something happens then it's your responsibility. (HO3)

Here, again, assessment practices are described which foreground issues associated with short-term risk of harm to others and the potential for the respondent to be held responsible should a prison leaver reoffend.

A supposed advantage of multi-disciplinary working is that a range of perspectives are brought to bear on a single issue (Nash and Walker, 2009). However, in the above extract, joint working manifests itself by the respondent receiving information from staff in these agencies, and then taking on their priorities and concerns. So, there was very little evidence of constructive debate between staff across the 'promote opportunities/ managing risks' divide.

Some Housing Solutions staff specialised in working with prison leavers. They had been given designations which defined them primarily as offender managers. As an illustration of this, in the following extract a respondent's accounts for their employment status:

I was on the frontline doing homeless stuff, housing options and as part of that role as well I was covering the offender manager when they were on leave, when he was on holidays. (HO10)

As Bourdieu (1991) states, the act of naming establishes reality. Titles have significant implications for how priorities are perceived, and an 'offender' manager role translates easily to a fixed view of prison leavers as destined to offend again. Like all job titles, 'offender manager' adheres to distinct ideological interests. 'Offender Managers' are of necessity embroiled more in the public protection concerns of a criminal justice system than in meeting accommodation needs.

\section{Discussion and conclusion}

In a previous report (Madoc-Jones et al., 2018) and article (Madoc-Jones et al., 2019) we have shown that despite the preventative turn in Wales, the housing needs of prison leavers are still not being adequately assessed and addressed. In this article we have sought to explore why this might be the case in more depth. We have argued that homelessness prevention is an imaginary penality (based on imaginary prisons, prison leavers, communities and resources) and this gives rise to 'imaginary practice' whereby practitioners focus on the routines of their work and only 'as if' what they do is meaningful.

In a number of publications, the ability of housing staff to use discretionary powers to disadvantage prison leavers from accessing their legal right and entitlement to housing has been noted (Lidstone, 1994; Alden, 2015). We found very little evidence, however, of mendacious conduct. Conversely, we suggest homelessness prevention practice in Wales 
is a form of imaginary penality. As Carlen (2013) identifies, imaginary penalities and the bureaucratic routinisation they underpin arise when there is a gap between policy objectives and the wider social context in which those objectives have to be met. We have outlined features of this context. Dominant political and populist ideologies on crime underpin mass imprisonment and the use of short-term sentences. The prison population of England and Wales has increased rapidly over the last few decades (House of Commons, 2017). A sizeable proportion of the more recent upsurge in the use of custody relates to a very sharp increase in the number of individuals recalled when their 'resettlement from prison' was not successful - up from 13,252 in 2007/2008 to 21,721 in 2016/2017.

We have outlined the perfect storm of public sector cuts and Welfare Reform that has worsened the economic situation of some of the more vulnerable members of society, which includes most prison leavers. These reforms have reduced the stock of available properties for prison leavers to occupy and rendered those dependant on benefits, such as prison leavers, the least desirable as tenants. Imaginary homelessness prevention practices with prison leavers was legitimised through the imaginary and two additional processes. The first, resonating with neo-liberal discourse about the causes of homelessness, involved staff focusing on a prison leaver's responsibility for their homelessness, as opposed to their right to housing. The second, echoing broader concerns with 'risk' was associated with staff focusing on the contribution they could make to the criminal justice goals of managing risk and public protection. Partnership working in the criminal justice system has often come with these consequences. Kemshall and Maguire (2001) argue, for example, that the more contact they had with police, the more probation officers became preoccupied with policing priorities. Similarly, Harvie and Manzi (2011) have documented how the reformist zeal of some voluntary organisations became diluted when they engaged with the criminal justice system. Crawford (2003) has referred to the spread of 'policing' through housing opportunities. Moreover, social landlords are increasingly becoming instruments for monitoring and reporting back to the criminal justice system on the behaviour of tenants.

We conclude by drawing out the lesson from Wales which is that since the problem of homelessness amongst prison leavers has its roots in governmental rationalities, relatively minor policy and procedural changes may struggle to make a significant impact on the issue. For example, in Wales prison leavers had priority need status for housing between 2001 and 2014 and, even then, they fared little better (Humphreys and Sterling, 2008; Bibbings, 2012). Conversely, we propose that preventing homelessness amongst prison leavers may be achieved only as an adjunct to a less punitive approach to justice and homelessness; conferring the right to permanent stable accommodation onto all homeless peoples (without reference to priority need or intentionality) and a more radical programme of (social/affordable) housing building.

The new justice sensitivity we are advocating does not depend on revolutionary change. Its foundations are already established in that it is increasingly accepted that prison sentences, especially short ones, can trap people in a vicious cycle of minor offending followed by stigmatisation, homelessness and more offending. Hitherto, the solution to this has taken the form of bolting onto a system that creates this harm, a process for undoing that harm. As the evidence that such an approach has limited effect increases, and is witnessed on the streets, so it becomes more likely that the advantages of not inflicting the harm in the first place will be identified. Since 2018 the Justice Minister, as well as the Justice Select Committee at Westminster, have advocated for sentences of 
under twelve months in custody to become the last resort or abolished (Grierson, 2019). Whilst conferring the right to permanent stable accommodation to all may seem prohibitively expensive, it is a policy option that is currently gathering momentum in Wales. A similar rights-based policy was introduced in Scotland in 2012. Although this was initially associated with significant increases in demand for temporary and then permanent accommodation, this was in the context that preventative practices had not already been developed to the extent that they have been in Wales. A rights-based approach to housing is congruent with the Welsh Government preference for universal services (Connell et al., 2017) and a Housing First approach which conceives stable accommodation as a basic 'human right'. A focus on rights better supports an inclusive vision for working with prison leavers and provides a vocabulary to challenge and undermine exclusionary risk-based penalties.

\section{References}

Ahmed, A. and Madoc-Jones, I. (2019) 'Introduction: homelessness prevention in an international policy context', Social Policy and Society, doi: 10.1017/S1474746419000393.

Alden, S. (2015) 'On the frontline: the gatekeeper in statutory homelessness services', Housing Studies, 30, 6, 1-18.

Bibbings, J. (2012) Policy Briefing: Homeless Ex-offenders in Wales, 2010/11, Shelter Cymru, https:// sheltercymru.org.uk/what-we-do/policy-and-research/policy-briefing-ex-offenders [accessed 01.08.2019].

Bourdieu, P. (1991) Language and Symbolic Power, Cambridge: Polity Press.

Canton, R. (2010) 'Taking probation abroad', European Journal of Probation, 1, 1, 66-78.

Carlen, P. (2013) Imaginary Penalities, London: Routledge.

Clinks Briefing (2017) Are the Accommodation Needs Being Met for People in Contact With the Criminal Justice System?, https://www.clinks.org/sites/default/files/basic/files-downloads/accommodation_for_ people_in_contact_with_the_cjs-_feb_2017.pdf [accessed 05.04.2019].

Connell, A., Martin, S. and Denny, E. (2017) 'How can subnational governments deliver their policy objectives in the age of austerity? Reshaping homelessness policy in Wales', Political Quarterly, 88, 3, 443-51.

Cooper, V. (2013) 'No fixed abode: the continuum of policing and incarcerating the homeless', Policing: A Journal of Policy and Practice, 11, 1, 29-38.

Cooper, V. (2016) 'It's all considered to be 'unacceptable behaviour': criminal justice practitioners' experience of statutory housing duty for (ex) offenders', Probation Journal, 63, 4, 433-45.

Cowan, D., Pantazis, C. and Gilroy, R. (2001) 'Social housing as crime control: an examination of the role of housing management in policing sex offenders', Social and Legal Studies, 10, 4, 435-57.

Crawford, A. (2003) 'Contractual governance of deviant behaviour', Journal of Law and Society, 30, 4, 479-505.

Dwyer, P., Bowpitt, G., Sundin, E. and Weinstein, M. (2014) 'Rights, responsibilities and refusals: Homelessness policy and the exclusion of single homeless people with complex needs', Critical Social Policy, 35, 1, 1-21.

Feeley, M. and Simon, J. (1994) 'Actuarial justice: the emerging new criminal law', in D. Nelken (ed.), The Futures of Criminology, London: Sage.

Fitzpatrick, S., Pawson, H., Bramley, G., Wilcox, S. and Watts, B. (2016) The Homeless Monitor: England 2016, https://www.crisis.org.uk/media/236829/the_homelessness_monitor_england_2016_es.pdf [accessed 09.09.2019].

Flint, J. and Nixon, J. (2006) 'Governing neighbours: anti-social behaviour orders and new forms of regulating conduct in the UK', Urban Studies, 43, 5-6, 939-55.

Garland, D. (1997) 'Governmentality' and the problem of crime', Theoretical Criminology, 1, 2, 173-214. 
Gojkovic, D., Mills, A. and Meek, R. (2012) Accommodation for Ex-offenders: Third Sector Housing Advice and Provision. Third Sector Research Centre, https://eprints.soton.ac.uk/337980/1MP77_ Accommodation_for_ex-offenders_-_Gojkovic\%252C_Mills_and_Meek\%252C_March_2012\%255B1\% 255D.pdf [accessed 09.09.2019].

Grierson, J. (2019) 'Abolish prison terms of under a year to ease safety crisis say MPs', The Guardian, 3 April.

Harvie, P. and Manzi, T. (2011) 'Interpreting multi-agency partnerships: ideology, discourse and domestic violence', Social and Legal Studies, 20, 1, 79-95.

House of Commons (2017) UK Prison Population Statistics 20 April 2017, London: House of Commons.

Humphreys, C. and Sterling, T. (2008) 'Necessary but not Sufficient: Housing and the reduction of re-offending. Welsh Local Government Association', Cardiff; Welsh local Government Association.

Kemshall, H. and Maguire, M. (2001) 'Public protection, partnership and risk penality: the multi-agency risk management of sexual and violent offenders', Punishment and Society, 3, 2, 237-64.

Lidstone, P. (1994) 'Rationing housing to the homeless applicant', Housing Studies, 9, 4, 459-72.

Mackie, P. (2008) This Time Round: Exploring the Effectiveness of Current Interventions in the Housing of Homeless Prisoners Released to Wales', Swansea: Shelter Cymru.

Madoc-Jones, I., Gorden, C., Hughes, C., Dubberley, S. and Washington-Dyer, K. (2019) 'Rethinking homelessness amongst prison leavers', European Journal of Probation, 10, 3, 215-31.

Madoc-Jones, I., Hughes, C., Dubberley, S., Gorden, C., Washington-Dyer, K., Wilson, F., Ahmed, A., Lockwood, K. and Wilding, M. (2018) Evaluation of Homelessness Services to Adults in the Secure Estate (Wales) Final Report, Cardiff: Welsh Assembly Government.

Maguire, M. and Raynor, P. (2006) 'How the resettlement of prisoners promotes desistance from crime: or does it?', Criminology and Criminal Justice, 6, 1, 19-38.

Ministry of Justice (2012) Accommodation, Homelessness and Reoffending of Prisoners: Results from the Surveying Prisoner Crime Reduction (SPCR) Survey, London: Ministry of Justice.

Ministry of Justice (2019) Published Response to Revolving Door Agency (2019) FOl 180915001, https:// www.whatdotheyknow.com/request/homelessness_on_release_from_pri\#incoming-124060 [accessed 10.06.2019].

Nash, M. and Walker, L. (2009) 'Mappa - is closer collaboration really the key to effectiveness?' Policing, 3, 2, 172-80.

National Audit Office (2017) Homelessness, London: National Audit Office https://www.nao.org.uk/wpcontent/uploads/2017/09/Homelessness.pdf [accessed 19.12.2019].

Sibley, D. (1995) Geographies of Exclusion, London: Routledge.

Simon, J. (2007) Governing through Crime: How the War on Crime Transformed American Democracy and Created a Culture of Fear, Oxford: Oxford University Press.

Social Exclusion Unit (2002) Reducing Reoffending by Ex-Prisoners, London: Social Exclusion Unit.

Stephens, M. and Stephenson, A. (2016) 'Housing policy in the austerity age and beyond', in M. Fenger, J. Hudson and C. Needham (eds.), Social Policy Review: Analysis and Debate in Social Policy, Bristol: Policy Press, 63-85.

Ugelvik, T. (2016) 'Techniques of legitimation: the narrative construction of legitimacy among immigration detention officers', Crime, Media, Culture, 1, 2, 215-32.

Wakefield, A. (2003) Selling Security: The Private Policing of Public Space, Cullompton: Wilan.

Welsh Government (2015) The National Pathway for Providing Services to Children, Young People and Adults in the Secure Estate, Cardiff: Welsh Government.

Welsh Government (2017) National Rough Sleeper Count November 2016-Experimental Statistics, Cardiff: Welsh Government http://gov.wales/docs/statistics/2017/170201-national-rough-sleeper-count-november2016-experimental-statistics-en.pdf [accessed 02.03.2019].

White, A. (2013) 'The shadow state: probation chiefs voice doubts about outsourcing', New Statesman, 7 January. 